\title{
The Digital Spatial Fix
}

\author{
Daniel Greene ${ }^{*}$ and Daniel Joseph ${ }^{\dagger}$ \\ "University of Maryland, College Park, USA, dgreene1@umd.edu, dmgreene.net \\ ${ }^{\dagger}$ York and Ryerson Universities, Toronto, CA, daniel.joseph@ryerson.ca
}

\begin{abstract}
This article brings distinct strands of the political economy of communication and economic geography together in order to theorise the role digital technologies play in Marxian crisis theory. Capitalist advances into digital spaces do not make the law of value obsolete, but these spaces do offer new methods for displacing overaccumulated capital, increasing consumption, or accumulating new, cheaper labour. We build on David Harvey's theory of the spatial fix to describe three digital spatial fixes, fixed capital projects that use the specific properties of digital spaces to increase the rate of profit, before themselves becoming obstacles to the addictive cycle of accumulation: the primitive accumulation of time in the social Web, the annihilation of time by space in high-frequency trading, and affect rent in virtual worlds. We conclude by reflecting on how these digital spatial fixes also fix the tempo of accumulation and adjust the time-scale of Marxian crisis theory.
\end{abstract}

Keywords: crisis, geography, political economy, communications, spatial fix, David Harvey, digital media, social media, high-frequency trading, game studies, creative class

Acknowledgement: Many thanks to our Digital labour 2014 roundtable for helping us flesh out these ideas: Karen Gregory, Austin Walker, and Matthew Tiessen. And also to Jen Jack Gieseking and Mark Graham for comments on early drafts.

\section{Introduction}

In 1994, US telecommunications giant $\mathrm{MCl}$ was busy transitioning the Internet from a research network for specialists and hobbyists to a commercialized communications system that could potentially enter the offices, homes, and pockets of everyone on Earth. They had long been one of the private contractors managing the pre-Internet National Science Foundation Network (NSFNET) and were about to embark on their own ambitious fiber-optics construction project. Advertising that networkMCI plan was a young Anna Paquin, who appeared in an empty desert to tell TV viewers: "There will be a road. It will not connect two points. It will connect all points. Its speed limit will be ... the speed of light. It will not go from here to there. There will be no more there! There will be no more there. We will all only be here."

Capital has always pushed for faster and faster communication and transportation networks that would make distance and locality obsolete as the space between separate spheres of production, distribution, exchange, and consumption was erased. This fantastic desire for what Marx (1993a, 524) called "the annihilation of space by time" was embraced by the leading architects of MCl's network infrastructure, with Vint Cerf saying, "When you're in a fully networked environment, there isn't much in the way of 'there"' (Hafner 1994). This sort of millennial, liberal zeal for the end of distance and the free flow of ideas has circulated around communications technology for centuries (Mattelart 2000). While critics such as Morozov (2012) have often noted the utopian desire present in these predictions, such desires arise from real social contradictions, and the virtual possibilities of new technologies that often come up short (Mosco 2005). These technologies and their effects cannot be reduced to mere false consciousness or propaganda for the communications industry. Communications technologies really do change the geography of capitalism, and digital spaces really do provide new sites of accumulation. 
This is of course not only an opportunity, but also a danger, as crises move rapidly from one site to another. Critical political economy asks how the geography of capitalism forms and reforms itself to exploit labour anew, and how specific technological and organizational changes help craft new spaces of exploitation. We argue here that the digital spaces formed by technologies such as the Internet are experimental spaces where capital seeks freedom from contemporary limits: Old strategies of accumulation are re-attempted in new spaces and new strategies are crafted through trial and error in the never-ending quest to surpass or displace the internal contradictions which lead to crisis. The concept we use to describe this is the digital spatial fix. We use this concept to find new sites of accumulation and crisis formation. This shows that while the fundamentals of the cycle of capital circulation have not varied from Marx's original analysis, it has found novel methods, appropriate to the contemporary historical context, to attempt to escape its inherent limits.

Capital has long sought what David Harvey $(1981 ; 1981 ; 2001 ; 2003)$ calls a "spatial fix" to declining rates of profit and the possibility of over-accumulation: expansion into new or under-exploited geographies becomes a way to dispose of accumulated capital or to create fresh opportunities for new accumulation at faster rates than before. Digital spaces can act as outlets for the same sort of fixes we have seen in the past while providing new opportunities for exploitation and accumulation. Meanwhile, digital spaces potentially intensify and extend those same crises.

For Marx, capital is value in motion and so digital spaces, like older formations of fixed capital, are necessarily sites where that value is fixed in place to allow for value production; but that fixity, even if it is a fixity of Web platforms or warehoused servers, eventually becomes a barrier to further accumulation in need of a dose of 'creative destruction'. We will describe these new avenues and their interaction with physical pieces of capitalist geography below, but our main purpose here is less to catalog every possible strategy and outcome and more to provoke economic geographers to grapple with the materiality of digital media and for theorists of digital media to integrate their maps of technological spaces with the social relations of economic geography. The challenge is to map how and why a communications giant like $\mathrm{MCl}$ might seek to annihilate "there" and replace it with 'here', and what might come of their attempt.

It is important that we not consider digital spaces to be unreal or somehow divorced from the material world. This is the meaning many have in mind when speaking of the 'virtual', or the now-outdated "cyberspace" as a purely representational plane, but neither should materialists overcorrect and wholly identify, say, the mobile meet-up app Grindr with a brick-andmortar gay bar. They are not equivalent and there are things you can do in one that you cannot do in another, but the interaction between the space a bar takes up on Grindr and the space the bar takes up in a building tells us a lot about how virtual space really works. A few typed messages and pressed buttons on Grindr will alter the material configuration of the bar: people will get up and leave, or come to meet each other for sex in the bathroom, or maybe the owner will reconfigure that bathroom to keep it from becoming a cruising spot. The digital space of Grindr is thus a space of potential, an active engagement with what the bar might yet become.

This is what we mean when we talk about 'virtual spaces': Not spaces of pure representation or imagination, but spaces of Aristotelian potential, spaces to actualize what-might-be. Thus in what follows we use 'digital' to describe technologies based in the transmission and storage of binary code and 'virtual' to describe the more general state of becoming of which digital spaces are only a subset. After all, the paper maps that imperial powers used to divide Africa into exploitable chunks in Berlin in 1884-1885 were virtual spaces with very material effects, just as, from capital's perspective, something like Facebook's virtual map of relationships reorganizes social life into a form more amenable to accumulation (Griffiths 1986; Michalopoulos and Papaioannou 2011).

Surplus value production is here always still a matter of exploited labour directed by capital. Value is never merely imagined into existence by financial genius or cultural fetish. The old rules still apply even though the methods have advanced. In this manner, we can consider all of Harvey's "spatial fixes", and the revisions others have proposed (Brenner 1998; Her- 
od 2009; Jessop 2013) as "virtual fixes". Different pushes into new spaces will have different effects depending on the technologies, state policies, organizational forms, and social relations involved, yet all actively create new potentials for accumulation. The work that has to be done is in deciphering whether and how these potentials are actualized. Like Harvey, our perspective on the virtual fix emphasizes and builds on certain aspects of Marxian political economy in order to address a specific problem: in his case the historical geography of capitalist expansion, in our case the role of digital technologies in crisis formation. Marx emphasizes this sort of virtuality, implicitly, and explicitly, in his examination of labour power and circulation time. Because of the unique qualities of the labour power commodity it is always at risk for potential devaluation as capital threatens an external move (e.g. outsourcing, scabbing) or internal development (e.g. speed-ups, new machinery) which lowers the value of labour power. ${ }^{1}$ This is a virtual fix. In circulation the problem is turnover time and the struggle to reduce it. ${ }^{2}$ New transportation methods or means of communication and coordination that minimize the time assembled commodities rest in production facilities (i.e. "just-intime" production) keep capital in motion and reduce the potential for devaluation. This is a virtual fix.

By describing the search for virtual fixes across the materials of capitalism's history, we hope to show that our approach to today's digital spatial fixes is distinct from those approaches that attribute to the information economy both a radical newness and an unmooring of the means of production from material goods. Digital spaces are still material spaces: stored on servers, coded by humans, transmitted over cables or antennae, clicked with fingers. At the same time the precise nature of their materiality has important consequences for accumulation and crisis. Information can act in many different phases of the capital circuit but it is always materially embodied. As Graham (2013) argues, the 'cyberspace' metaphor reduces complex networks of social life to a single, immaterial plane. This reduction is useful for state or corporate actors trying to justify the tracking and regulation of activities difficult to pin down geographically, or proposing purely technical solutions to thorny political problems.

Our materialist ontology thus makes no Platonic distinctions between physical and digital labour or materials. It acknowledges that production and reproduction of humanity is entangled with digital technologies, and that these digital technologies are sites of new forms of affective labour. At the same time, it doesn't privilege them above other forms of labour that aren't directly tied to digital technologies. It is important to reiterate that, like Boutang (2012), Fuchs (2012) and Dyer-Witheford (2015) we believe the labour theory of value holds, even as labour is increasingly fragmented, skilled, reskilled and deskilled. That so much labour in the digital economy is unwaged does not change the fact that valorization is still realized by companies like Facebook or Twitter. The question of unwaged audience and user labour was best examined and answered in 1977 by Dallas Smythe. We believe his work on the audience commodity in network television still sets the starting point for understanding the production of value in what appears at first glance to be the opposite of the traditional factory. Smythe's work, explored below, shows Marx's original conception of abstract general labour can be updated to take into account these new forms of affective labour (Fuchs 2010). In the

\footnotetext{
${ }^{1}$ After all, the labourer is "free of all the objects needed for the realisation of his labour-power" and so must seek out the capitalist, who owns the means of production, in order to realize this potential (Marx 1990, 272-273).

2 "As long as it persists in one of these phases-[as long as] the phase itself does not appear as fluid transitionand each of them has its duration, [then] it is not circulating, [but] fixated. As long as it remains in the production process it is not capable of circulating; and it is virtually devalued. As long as it remains in circulation, it is not capable of producing, not capable of positing surplus value, not capable of engaging in the process as capital. As long as it cannot be brought to market, it is fixated as product" (Marx 1993a, 620-621). The original German for this sentence is "Solange es im Produktionsprozeß verharrt, ist es nicht zirkulationsfähig; und virtualiter entwertet." "Virtualiter" is an arcane Latin form that, for Marx, requires its own footnote definition as "potentiel" (Marx 1953, 538). Aristotelian philosophy had a strong influence on Marx's own theoretical growth (Meikle 1991). That general affinity, combined with this specific reading of virtual as potential, would seem to vindicate our general interpretation of Marxian relations (e.g. the value of labour power, the composition of capital, the length of turnover time) as virtual relationships wherein future states exist as potentials that are actualized from the materials of present states, rather than ontologically distinct phases through which something like money or workers circulate. Many thanks to Quinn Slobodian for assistance with this translation.
} 
end they are the sources of value that are exploited by capital as it is increasingly faced with a variety of contradictions, struggles and crisis.

Indeed, this is the task of any rigorous theory of capitalist technology: To track the historical, geographic, and sociological development of the labour-capital relation and its precise materialization. Too often, such theories emphasize either a sharp break with both the materials of prior modes of production, erasing the development and repetition of capitalist strategies to resolve accumulation crises, or the labour theory of value on which industrial labourcapital relations are said to rest, erasing the endless technological advances aimed at controlling, repressing, or extracting labour's unique ability to produce value. Hardt and Negri (2000) are symptomatic of these tendencies. They argue that value is now beyond measure, thus making the labour theory of value politically and empirically obsolete, and that labour in this new mode of production is largely "immaterial"-either producing a non-physical commodity, participating in "informationalized" industrial production, or working mainly in symbol analysis (293). Our analysis of new digital spatial fixes, especially the "primitive accumulation of time" that develops from earlier, similar strategies, demonstrates that the struggle to capture, measure, and valorize surplus labour time is still at the core of the contemporary labourcapital relation. This analysis proceeds under the assumption that "immaterial labour" is anything but (Caffentzis 2007). Work that produces affects is always deeply embodied, as in the centuries of "women's work" required to reproduce capitalism. The informationalization of production is always reliant on "dirty" labour-intensive industries elsewhere on the supply chain. And service or cultural work always relies on fixed capital projects and always produces commodities that, though they may not be physically tangible, are certainly material in their production and consumption (e.g. the millions of working hours going into a big-budget video game).

In what follows we will briefly situate our description of digital spaces as fixes for overaccumulated capital within the literatures of the political economy of communication, geographies of economic crisis, and theorizations of the "network society". Then, mirroring Harvey's description of three spatial fixes, we will describe three experimental digital spatial fixes we see operating in the current political economy: the primitive accumulation of time in social media, the annihilation of time by space via financial infrastructure, and the rise of affect rent in marketplaces for digital commodities. We conclude by reflecting on the questions these conceptual foundations pose for further research, especially regarding the links between these digital spaces, the temporality of accumulation, and more traditional geographies of crisis. The goal throughout is not to catalog the potential of digital spaces to act as spatial fixes, but to model a spatial approach to digital media.

\section{Political Economy of Communication: Concentration, Agglomeration, and Commodification}

Communication technologies create new spaces and rewire old ones. Our work specifically addresses how capital in its current formation has embraced the space of the Internet and the attendant technologies it has enabled. While the political economy of communication has long incorporated space as a key concept and topic of analysis, those that need addressing in relation to our argument concern the study of concentration, agglomeration and the commodification of audiences.

Studies of concentration tend to focus on the concentration of ownership, rather than physical geographic concentration. It not only brought forward questions of vertical and horizontal integration but also the technologies and organizational forms that allow for such concentration (Chandler 1977). Likewise, in studying phenomena such as the cross pollination of various boards of directors with board members from other, competing firms, studies of concentration revealed how hegemony within industry itself was maintained (Burt 2012; Scott 2012).

Our interest in space and its relationship to capitalism, however, is more related to physical geography then what concentration studies offered, and thus our affinity lies more with agglomeration studies. As a method it moved beyond investigations of direct ownership and 
outright mergers and towards the study of industrial ecosystems in bounded geographic spaces, the built environment of industrial production, and how various kinds of capital supplement each other. Agglomeration studies was one response to theories of the "network society", which suggested that communication technologies would implicitly create less reliance on spatial co-presence. Agglomeration studies challenged this, suggesting that regional geographic spaces would become more important for capital, not less (Mosco 2009). In this way agglomerated industrial development is positioned as a virtual fix, potentially solving the crisis of vertical integration. The rise of Web startup culture, alongside the still in-vogue concept of the "creative city"-which emphasizes the comparative economic advantages of cities based on scales of agglomeration rather than concentration-would suggest that agglomeration studies provided a powerful analytic to understand the impact of new technologies on capitalism's use of space.

The commodification of human communication has also been an important area of study in the political economy of communication. Dallas Smythe's (1977) intervention was to specifically ask what the economic function of advertiser-supported media is. He proposed that they produced an "audience commodity". He argued that prior Marxist accounts focused all too often on the media and communication industries as ideology machines, suggesting that they were merely a function of the "base" in Marx's base and superstructure metaphor. For Smythe this critique avoids the answers that careful materialist analyses of the communication industry could reveal. He writes:

This is the threshold question. The bourgeois idealist view of the reality of the communication commodity is "messages", "information", "images", "meaning", "entertainment", "orientation", "education", and "manipulation". All of these concepts are subjective mental entities and all deal with superficial appearances. Nowhere do the theorists who adopt this worldview deal with the commodity form of mass communications under monopoly capitalism on which exist parasitically a host of sub-markets dealing with cultural industry, e.g. the markets for "news" and "entertainment" (2).

What follows from this critique is his assertion that broadcast media is, at its core, a realm of unwaged labour. The commodity that broadcasters sell to advertisers is the audience and their attention. Smythe says that the content that broadcasters distribute is akin to the "free lunch" once offered by restaurants and pubs to encourage the purchase of profit making alcoholic drinks (5). This is not to suggest that the content of broadcasters doesn't itself have a variety of artistic or cultural or propagandistic use values but rather that it is secondary to the transaction. In this way, Smythe reveals how Marx's concept of the commodity fetish functions: the primary appearance of the commodity's use value (messages, entertainment) mystifies the commodity's real value as exchange value (audiences sold to advertisers). The audience's labour time viewing advertisements is sold (Meehan 1993). The audience is then "paid" in media content, which the worker cannot actually use to reproduce themselves, meaning that the labour is unwaged.

In the political economy of communication, and communication studies generally, Smythe's work had a lasting impact on how media has been understood, especially juxtaposed with other popular theories of communication technologies under capitalism. Broadly speaking, on one side stands the interpretation of media primarily as purveyors of content and ideology, with either the Frankfurt school's psychoanalytic and Marxist (Habermas 1991; Horkheimer and Adorno 2007) framework or the media ecology of Marshall Mcluhan (1994; 2008). Theories that utilize Smythe's work, on the other hand, place this or that media industry into the wider economy and the production of exchange value. It is the latter with which we align. For example, Vincent Mosco's analysis of the disjoint between the ideology of technological utopianism and the material economic effects is the core of his work both on the early dot-com boom (2005) and his recent work on the realities of cloud computing (2014). Studies of audience labour online (Nixon 2014), intellectual property and rent extraction (Rigi 2014), and the relationship between games and labour (Lund 2014) have all utilized Smythe's typology. In a similar vein, but not necessarily engaged with Smythe's work specifi- 
cally, Dyer-Witheford (1999; 2015) and Dyer-Witheford and de Peuter (2009) have contextualized communication and cultural industries with theories of autonomist Marxism, communisation theory, game studies and Deleuze's (1992) later work.

Our argument extends prior theories of unwaged labour into a discussion of capital's spatial advances. That capital, when given the opportunity, meshed itself into the fabric of the airwaves-into the radios and televisions of the private home itself-is an example of the kind of virtual fixes we are interested in building a method to discover. It should come as no surprise that modern social media platforms and other Internet-based services offered for "free" are much the same kind of free lunch and unwaged labour relationship that Smythe identified in the 1970s. What is important to note is that is that these services engage in a spatial strategy that is informed by, but distinct from, prior media forms.

This then extends into the study of industrial agglomeration, the impact this has on urban development, and the development of specific urban governance strategies that privilege the development of "entrepreneurial" (often Internet-based or -reliant) capitalism (Harvey 1989), often at the expense of those parts of society either unwilling or unable to engage in this new economy. The political economy of communication's focus on the spatiality of ownership is also important, in that monopolization and strategic partnerships is a key aspect of new kinds of spatial fixes on take place online. Owning the platforms and software is a new virtual fix in the same way land rents were a novel strategy at the birth of industrial capitalism.

\section{The Geography of Economic Crisis}

Since the 1970s, a generation of geographers have investigated how crises of capitalism develop within and spread across the world market and the built environment. This political economic perspective has its roots in a variety of Marx's scattered spatial critiques. One such observation is the dialectic formed between the homogeneity of a world market and the geographical division of labour required for profitable commodity production. Another is that ever-faster communications and transportation infrastructure are necessary to overcome barriers to the circulation of capital and so function as the "annihilation of space by time" (Marx 1993a, 524). With respect to crisis formation, the basic contradiction here is that capital, as value in motion, must be frozen in place in order for accumulation to occur. This may come in the form of technological investment, a particular organizational form, or investment in physical or social (e.g. highways, schools) infrastructure that increases the speed and volume of circulation or the productivity of labour. This fixity means capital is necessarily overaccumulated locally over time, as the initial opportunities to employ it profitably decrease due to capitalist competitors deploying more effective means of production elsewhere, the working-class organizing around the geography of accumulation, or demand flagging for the glut of commodities. Money saved, means of production, infrastructure or labour power itself will then be devalued, or new territories of accumulation sought out (Harvey 1981). David Harvey describes capital's geographic dilemma in this way:

It has to build a fixed space (or "landscape") necessary for its own functioning at a certain point in its history only to have to destroy that space (and devalue much of the capital invested therein) at a later point in order to make way for a new "spatial fix" (openings for fresh accumulation in new spaces and territories) at a later point in its history $(2001,25)$.

Harvey's $(1981 ; 1982 ; 2001)$ signal contribution to this field was to unify Marx's spatial critiques and build on them to craft a theory of how crises can form within some capitalist geographies and be resolved by others. To do so, he raises interest rates and land rents to the same level of priority as wages in the struggle over surplus value. In his "first cut" theory of crisis, the struggle over wages manifests as an ongoing increase in machines' role in production and the trend towards the devaluation of that fixed capital. In the "second cut" theory of crisis, the interest rate functions as the measure of the socially necessary turnover time embodied in fixed capital and the credit system, as the nervous system coordinating capital flow, then becomes a means to displace or delay crises of over-accumulation over time. In the "third cut" theory of crisis, land rent is theorized as a future claim on fictitious capital and the 
means of coordinating those capitals. But this coordination is a site of intra-capitalist conflict and fights regularly break out over just which sites, with which relative geographical advantages, can best further accumulation.

This, Harvey (1981) argues, is why Marx concludes Volume 1 of Capital with what appears to be a digression into Ireland's history as a British colony: because capital is constantly searching for a spatial fix which can resolve the crisis of frozen capital by creating new markets to combat underconsumption, by outsourcing production to sites with a higher rate of profit, or by the primitive accumulation of cheaper labour abroad. This search for a spatial fix, a global solution to local over-accumulation, leads to the persistent displacement of crises from one geography to the next. Other researchers have built on Harvey's theory to argue that crisis formation and resolution appears not just as a fix for the location of capitalist activities, but the scale of those relations: an imperialist push for uneven development succeeded by post-WWII Keynesian states succeeded by financial networks focused on regional competition and transnational corporations (Brenner 1998).

A particularly rich vein of research has focused the spatial fix perspective on the specific questions of postwar urbanism. Neil Smith (2002) argues persistently that the state-assisted redevelopment of once-abandoned Western inner cities has been a key site of accumulation since the 1970s, especially after the flight of large-scale industrial production from these sites. Feminist geographers such as Melissa Wright (2001) find other fixes in the movement of certain aspects of production and reproduction from waged work to unwaged housework (and back again), as well as the gendered and sexualized aspects of the restructuring of urban economies. This re-fixing often upsets the established social order leading to the activation of police powers to ensure the demolition of legacy structures and to manage the labourers rendered surplus by automation or outsourcing (Wacquant 2009).

In updating the spatial fix framework, it is important to emphasize Harvey and Smith's approach to relocation and redevelopment as both cause of and solution to crises of overaccumulation, especially in the former's focus on "fix" as not only situatedness or solution, but also addiction (Harvey 2001). But in exploring how capital moves between various sorts of physical and digital spaces, we take as a model the feminist Marxist interventions which track the movements of the work of social reproduction from home to state to market as a sort of virtual fix (Luxton and Bezanson 2006). This approach will become clearer when contrasted with some of the dominant theorizations of the present mode of production as a 'network society'.

\section{Network Society in Crisis}

Following the fall of the Berlin Wall, 1990s New Economy boosters celebrated a fully globalized economy where commodity production became weightless and placeless (Huws 1999). A number of researchers, largely sociologists, tamped down on these millennial claims while still rigorously arguing for an epochal shift from an industrial society to an information society or network society whose main hallmarks were 1) a capitalism with a largely informational character, where, for example, the paradigmatic product is software rather than automobiles and 2) a global networked geography where places gain command roles not primarily through their relationship to the nation-state but through their position in and power over networked 'flows' of information. A materialist theory of crisis formation necessarily departs from this tendency towards stagism in order to focus on the materiality of technology and the continuity between modes of production. ${ }^{3}$ But while the network society critique may lack a unified theory of crisis-partly because it is hard to imagine an over-accumulation of the imma-

\footnotetext{
${ }^{3}$ Both Castells and Sassen, the main critics reviewed below, have a background in Marxian political economy but their most celebrated works depart from this perspective. Castells for example was trained by Alain Touraine but later became a strong critic of Henri Lefebvre's Marxist humanism. And while Network Society (2009) does take a stand against "that dwindling stream of economic theory still concerned with the real economy" (78), its only mentions of Marx are offhand dismissals $(78,222)$. The work itself also engages in what could be labelled idealism, as in Castells' discussion of Internet firms' market capitalizations as an example of 'the creation of value out of our belief in the value we create" (161).
} 
terial-it is still the dominant argument in discussions regarding the changes global capitalism has undergone since the 1970s. Manuel Castells has focused on the social construction of space throughout his career but is best known for his encyclopaedic theorization of the network as the now-dominant social form (2009). This network society, compared to industrial society, is based on horizontal communications technologies and their widespread distribution of culture and labour; the diminished role of the nation state and the rise of the region and the transnational corporation in global politics; and new hegemonic experiences of space (determined not by place but by network location) and time (determined not by the sequence of the clock, but by social and economic requirements to disaggregate and reorder time). Castells distinguishes his formulation from common conceptions of a postindustrial "flat" world, which are untenable in the face of persistent uneven development. Instead, he argues that centres of informational power direct industrial production, and that new forms of 'just-intime' production would be impossible without networked modes of distribution. The most recent edition of Network Society addresses the 2008 global financial crisis, but does so to confirm trends identified in previous editions such as increasing securitization and internetworked financial systems. There is not a consistent theorization of crisis or a comparison with crises past, but a fearsome invocation of a new financial "global automaton" which no one can control (xx-xxii). Saskia Sassen's (2001) research shows how globalization concretizes into command centres for informational capitalism: "global cities" such as New York, London, and Tokyo. Such cities are centres for producer services-a sector of intermediary firms in the Finance, Insurance and Real Estate (FIRE) industries but also management, design, and high-tech maintenance, with a largely business-to-business orientation. In so doing each city becomes a "partly de-nationalized platform for global capital" (Sassen 1999, 86). In describing the agglomeration effects of producer services and these firms' efforts to denationalize some but not all of a region's economic infrastructure, it becomes clear that networks both human and technical are always material and that specific places produce specific networks with specific orientations via their emergence in some places but not others (Sassen 2001). ${ }^{4}$ Because her study focuses directly on the re-working of global finance following the fall of Bretton Woods and the urban gentrification that is a partial result of producer services agglomeration, Sassen does offer a gesture towards links between space, technology, and crisis. There is both a Schumpeterian sense of the necessity of old decline for new growth in her description of retail and real estate in global cities, as well as a recognition of Harvey's point that capital mobility is dependent on spatial fixity. But the two critiques do not necessarily join. A description of crisis formation may be beyond Global Cities' scope but the work there does form an important part of a broader critique of the "flow" concept as an immaterial, bloodless descriptor of capital hypermobility (see also: Mezzadra and Neilson 2008).

While the shape and pace of the movement is a matter is of much debate, it cannot be contested that capitalism's expansion has always entailed some forms of both globalization and the interconnection of communications networks. Mattelart (2000) argues that networked enterprises like railways and telegraphs were the progenitors of a, "capitalism with global ambitions", always accompanied and empowered by liberal ideologies of free trade and free speech. Beniger's (1989) mapping of the "control revolution" 5 finds an economy led by information processing rather than physical goods production emerging not in the 1970s but the 1930s, with roots extending much earlier. This is an explicitly crisis-based theory where communication technologies help to coordinate and stabilize out-of-control economic materials. For example, regular train crashes demanded a standardized timekeeping system and a communications system to manage it, while whole new methods of branding, market re-

\footnotetext{
${ }^{4}$ Geographers and political economists such as Smith (2002) point out that by prioritizing the role of the global city in contemporary capitalism, Sassen may be mistaking command functions for production proper. This is because the city remains a key site for production the world over, especially Asian, Latin American and African cities, which did not see the mid-century Fordist-Keynesian compact between state, labour, and capital that Sassen describes as weakening in global cities. This charge may be true, but can be corrected by putting Sassen's global cities theory into conversation with critiques of urban production in the Global South, which she does herself in later work $(2009 ; 2014)$.

${ }^{5}$ Not to be confused with Deleuze's theory of the control society.
} 
search, and public relations were able to coordinate consumption and align it with new productive capacity. While focused more on communications theory than political economy, Beniger's materialist critique of the links between industrial and informational economies is a helpful methodological guide for what follows.

\section{Crisis Moves}

Harvey's (1981) original theorization of the spatial fix gave three basic strategies for resolving local over-accumulation and impending devaluation, each infinitely variable: exporting capital for production, creating new markets abroad to resolve local underconsumption, and increasing the size of the proletariat through primitive accumulation. In a similar spirit, we offer three fixes that digital technologies make possible: the primitive accumulation of time, the annihilation of time by space, and the creation of affect rent. Each will be described as they currently operate and their crisis tendencies demonstrated. Importantly, we see each potential fix as a prototype-strategies which capital will refine and broaden over time. Similar prototyping can be seen throughout history, as American manufacturing firms first left cities for suburbs, then North for South, then Mexico for China, etc. Or as the Portuguese developed the trading and management of slaves on the island of Sao Tome in the sixteenth century before expanding to the Americas (Davis 2006).

\subsection{The Primitive Accumulation of Time}

Marx used "primitive accumulation" to refer to the historic movements wherein land-held-incommon was privately enclosed, feudal were obligations dissolved, and labourers were divorced from spaces of social reproduction and forced to sell their labour to capitalists for a wage (Marx 1990). Subsequent re-examinations of Marx's critique found in it not primarily an historiographic commitment to locating the single, original moment of the creation of the European industrial proletariat. Rather, it reflected Marx's ontological commitment to tracing how the reproduction of the labour-capital relation always relies on the forced separation of labourers from the pre-capitalist means of production in order to commodify resources and grow the proletariat (De Angelis 2001). Highlighting the ongoing nature of this capitalist violence, Harvey terms these movements "accumulation by dispossession". Glassman (2006) positions Harvey's critique within a variety of feminist, anti-colonialist, and environmentalist critiques of the "extra-economic" means of accumulation that proceed today in a variety of spheres: capitalists' local reliance on not-yet-proletarianized workers and their resources, "capitalist appropriation of the gendered labour of social reproduction" (617), and the enclosure of resources previously held in common. The latter may manifest as the commodification of natural resources such as forests, the privatization of welfare state functions and the redistribution of that capital in capitalists' favour, or the transformation of cultural traditions or genetic information into "intellectual property". Capital relies on some non-capitalist spaces for social reproduction, but regularly invades and restructures others to fix falling profit rates. Harvey (2003) sees these capitalist raids of proletarian resources as particularly active in the neoliberal era, a shortcut around persistent difficulties with restoring the profit rate within production proper.

We use "primitive accumulation of time" to refer to the profit model of social networking sites and most of the free Web: access is free but your activity is enclosed and recorded so that your patterns of socialization can be packaged and sold to data brokers and advertisers. It is a quantitative development of Marx's original concept, taking advantage of extraeconomic means of coercion in new social spaces in order to accumulate not new labourers but tiny slivers of labour time. Sites such as Facebook maintain their rate of profit by regularly changing their interface to maximize recognizable and brand-friendly forms of socialization (e.g. the EdgeRank algorithm individualizes Facebook's home page for each user, focusing them on the people and brands with whom they are most likely to interact) and to encourage such socialization in new spaces (e.g. Facebook's push to become a universal login for other websites and the proliferation of the Like button). 
This strategy of course predates the current generation of social networking sites and will surely outlast them. Indeed, the first dot-com boom was partly driven by a speculative fever for the possibilities of gaining massive audiences in new spaces such as America Online and then directing them to advertisers or paid services. The free labour of the user is the core of the free Web and the free Web is quite lucrative: around $\$ 503$ billion is spent on online advertising each year. In 2011 alone, Facebook, with only 4,000 paid employees but with 845 million unpaid users spending approximately 64 billion hours on the site per year, made $\$ 1$ billion in profit at an astounding 50\% profit rate (Fuchs 2012).

This strategy is principally about finding new times for the production of surplus value, miniature working days which can be activated in everyday spaces. The social Web is always on, and its tracking algorithms do not discriminate between work or play, home or away, day or night-except insofar as the specific user labour in these spaces and times can be differentially valued and commodified. Each scroll, click, and share is an opportunity for accumulation of surplus labour time. Facebook's implementation of the Like button across diverse Web spaces is paradigmatic in this regard, though not qualitatively different from other social bookmarking icons. Where the dominant image of Web 1.0 was "surfing the web", an aimless wandering among different, disconnected cultural corners, the dominant image of Web 2.0 has been "sharing" through Facebook's white-and-blue thumbs up button, tucked amongst content all over the Web. Working under a pretext of social connection, the Like button collects users affective responses, shares them with peers, allows content producers to syndicate across platforms, and enables Facebook to become a central hub for the collection, storage, and brokerage of online affect (Gerlitz and Helmond 2013). This collection can occur over breakfast, at work, on the train, or in bed. And it explains why social networking sites have found the mobile Web-where collection is both convenient for the user and locatable for the data broker-so valuable and why they are major sponsors for mobile Web expansion in developing markets (Talbot 2014). This enclosure of social wandering, of surplus labour time that happens any time, is one reason why Web giants like Google are making big investments in the "Internet of Things"-the internetworking of home appliances and urban infrastructure (Thomas 2006) - so that data points can potentially include not only liking a video or searching for a restaurant, but your thermostat schedule or the rate at which your milk carton empties (Whitney 2014).

The capitalist struggle to increase surplus labour time is not new. What is novel is how digital media help capture that time during other times, including when the labourer is nominally working for someone else! The experience is familiar: you either finish with the day's tasks early on or you shift your attention out of boredom. Either way you end up moving from the spreadsheet or email or cash register to something more interesting on a mobile phone app or on another tab on a browser. Because productivity has generally increased with the introduction of new technologies, socially necessary labour time has generally decreased and white-collar workers are increasingly spending more of the work-day working for social media companies rather than their employer. This is where digital media companies take advantage of other employers' downtime, stealing the surplus labour time when we're on the clock at one job and converting it into surplus Likes, shares, and clicks.

It is important to note that it is labour time, specifically, being accumulated here and that, as in in other moments of primitive accumulation, this is often not freely given. Labour time embodied in the commodity form is at the core of the circulation of capital, and the capture of surplus labour time is at the core of the reproduction of that circuit. ${ }^{6}$ This fix does not necessarily accumulate a new, distinct set of labourers who were not previously proletarianized,

\footnotetext{
${ }^{6}$ Of course the real measure of value is not just any labour time but socially necessary labour time-and social necessity cannot be judged except at the end of the circulation process. Social networking sites may thus be "overvalued" not only in terms of their market cap being inflated through financial exchanges largely divorced from production, but in terms of over-accumulation. That advertising click-through rates remain low, that web content firms so often operate at a loss, supported by venture capital until they can figure out how to monetize a user base, may be a sign that they have accumulated millions of hours of user labour time but cannot find a sufficient market for it. The hours spent on these sites become the equivalent of unsold cars on the lot. Harvey $(1982,194)$ notes that this "tendency to produce 'non-values"' is a perpetual feature of the internal contradictions of capitalism.
} 
but rather accumulates tiny slivers of labour time throughout the day. This fix appears initially as an extension of Smythe's "free lunch" thesis, wherein Web users submit time spent clicking, blogging, and conversing to data miners in exchange for free content or social recognition. But this increasing sophistication is soon revealed as a qualitative development in the methods and scope of the "free lunch" model. In much of the social Web, users make their own free lunch: Social networking sites, for example, only host content produced by users for other users.

Users are also compelled to give up their labour time to capitalists online and this compulsion, and the subsequent spaces of labour, differ from that of broadcast media not just in degree but in kind. This coercion occurs in at least three, overlapping ways. First, as explored above, the primitive accumulation of time snatches labour time from other working days while it encloses other spaces of leisure and socialization that have been forced onto the monetizable Web; e.g. danah boyd (2014) describes how teenagers in the U.S. have been forced to interact on social networking sites as their access to physical public space has been reduced by moral panics, heavier policing, and a changing social geography that includes longer commutes and fewer malls and parks. Second, those learning to labour in the knowledge economy, at school or on their own, must build a "personal brand" and an audience of followers in order to begin to appear employable. Third, life online has become a "third shift" of reproductive labour wherein caregivers, who already work waged labour shifts and unwaged family shifts, must manage children's social lives and coordinate family activities-which might previously have taken place over the phone, after school, or over tea (Ammari et al 2015; Portwood-Stacer 2014).

Such coercion amounts, intentionally or not, to a forced repurposing of the infrastructure of social reproduction for a new accumulation regime. As Harvey (1982, 398-405) notes, both state-funded fixed capital projects (e.g. roads, schools) and the cultural superstructure atop them (e.g. standards of quality parenting) are built up to maintain specific accumulation regimes. Their fixity becomes an eventual barrier to increasing profit rates. "The social infrastructures which support life and work under capitalism" must then be taken apart, moved, or repurposed-generally in moments of crisis. Schools and libraries that provided industrial training now promote digital literacy, youth in isolated suburbs built on racial segregation and the automobile economy connect online as previous meeting places like malls become less viable. Parental supervision and coordination that previously occurred on the front porch or over the phone is pushed onto Facebook.

Conversations and clicks are not a priori raw materials of capital accumulation-"they want transforming into capital" (Marx 1990, 874). This transformation requires the separation of users from the means of socialization and the compulsion to spend free time on Web spaces built and maintained for profit. "Free labour" online is thus free not only in the sense that is unwaged but in Marx's original formulation of being free both from being means of production (i.e. Facebook owns user data but not actual users) and free from owning means of production (i.e. running a site like Facebook requires enormous amounts of capital investment). The transformation of free labourers' time into capital is a continual process that "not only maintains this separation [between capital and labour], but reproduces it on a continually extending scale" (874). This is both an intensive process and an extensive one. Intensive in that "the social means of subsistence and of production" (874), the tiny moments of care and contact that get labourers through the day, are ever more finely tracked, quantified, and commodified. Extensive in that new geographies of social life are constantly brought into the free labour process: Other working days, other moments to check the phone, other times the labourer's watch, clothes, or thermostat reports their activity, more and more online spaces brought into the same universal Facebook login or under the Like button.

The extensive movements, where more and more of the mundanities of social life are reduced by data mining to simple abstract labour, parallel Harvey's (1981) observation that a spatial fix is often sought via the proletarianization of latent reserve labour at home or abroad. These women and children are not initially considered fit labourers but when the profit rate falls, and especially when deskilling technologies are available, they can be plugged into the system just fine. Breathless press releases about the Internet of Things- 
among other innovations in the primitive accumulation of time-should be read with this in mind. The surveillance data from a microwave, a car, or a vital signs monitor may not have been worthy of capitalist consideration at one time, but today they are a priority for firms such as Apple and Google. These are latent reserves of labour time, and new technologies are being deployed to capture them; a tacit admission that the current scramble to commodify personal data has reached its limits and new slivers of user time must be accumulated from social spaces previously considered worthless.

This expansion into other working days, and the creation of tiny new working days within "downtime", is one reason why Web companies, and especially social media companies, remained profitable investments during the recent recession even while investors remained skittish of other sectors and hoarded funds (Lowrey 2014). This digital spatial fix is succeeding and is expected to succeed further. But success breeds competition and technological innovation. The race to generate and sell social activity online has led to a number of quickfix solutions, many automated: Bots that generate thousands of Likes, scripts that ping the comments section of several blogs back and forth, algorithmically-generated comments designed to boost traffic on one site or drive it elsewhere.

This is the classic introduction of labour-saving machinery under competitive pressure: social activity is a valuable commodity but one that can be generated faster by machine. Two problems emerge. First, the value of this productive activity cannot be finally realized in a sale; the bot won't buy the goods advertised to it because of its traffic pattern. Second, this generates less and less surplus value because, as fixed capital, its future productive output is already paid for. Because of the competitive pressure in this exploding market, such automated traffic makes up between a third and a half of overall Web traffic. Leaders in the online advertising community are terrified of the reality that large portions of the data profiles they're creating and selling are not human at all, but the products of machines made to thrive in the market advertisers created (Vranica 2014). So-called "linkbait" blogposts and comments, filled with gibberish that just links back and forth with other posts, thus signal overaccumulation and effective demand problems in the Like economy in the same way as new, unsold cars sitting on the lot do for the industrial economy.

With these fake hits and fraudulent traffic, we can see this digital spatial fix beginning to crash into its own limits. In order to increase the rate of profit, those relying on the primitive accumulation of time may need to excise this fraudulent traffic, thus lowering the mass of profits, or find new spaces from which to accumulate users' social activity. And so the push into mobile and "smart" objects or the digital commercialization of "public" spaces such as higher education become even more important.

\subsection{The Annihilation of Time by Space}

The second fix is, to flip Marx's famous maxim, the annihilation of time by space. And here we move from the everyday play of Farmville or Foursquare to massive construction projects such as Spread Networks' $\$ 300$ million attempt, funded by former Netscape CEO Jim Barksdale, to build, in secret, a single-use or "dark" fibre optic cable in as straight a line as possible from Chicago's futures markets to New York hedge fund data centres (largely located in New Jersey) in order to transmit buy orders as close as to the speed of light as possible and thereby take advantage of "tiny discrepancies between futures contracts in Chicago and their underlying equities in New York" (Steiner 2010). And while Spread worked regularly to straighten, repair, and fine-tune their data pipeline to gain every microsecond advantage, they were quickly overtaken by a competitor, Windy Apple Technologies, who had secretly completed a microwave relay system that transmitted orders even faster. Similar projects linking exchanges and data centres in London and Frankfurt are ongoing (Onstad 2014).

This is the infrastructure for "high-frequency trading" (HFT): Finance by algorithm at a speed no human can comprehend. As Golumbia (2013) explains, HFT is not just marked by high-speed networks but also by co-location intended to reduce latency; trading in microlevel time windows; sending numerous fast orders and cancels; and attempting to end the trading day "flat", with most money made on taking and changing positions rather than com- 
pleting large orders. Large institutional traders deplored this practice initially but now they are the main HFT players. Against the grain of some Marxian analyses, Harvey $(1982,377)$ theorizes transportation industries and infrastructure projects as large-scale efforts to capture increased relative surplus value, producing not a physical good but relative locational advantages. The intra-capitalist competition visible in this particular fix should be analysed in this way: Deploying massive amounts of fixed capital to annihilate ever smaller obstacles of time, pushing the transmission of data as close as possible to the fundamental limit of the speed of light in order to complete exchanges just a microsecond ahead of the competition.

Like the primitive accumulation of time, the annihilation of time by space is an extension and intensification of an older fix rather than a qualitatively different one. Where the annihilation of space by time refers to the reduction of turnover time through large fixed capital projects, like railways, that defeat geographic barriers to circulate goods as quickly as possible, we use the annihilation of time by space to mean the construction of communications infrastructure to gain a competitive advantage in exchange specifically and financial exchanges especially. Speed remains the competitive advantage, but the scale of it, faster than any human can process, creates a different relationship to spaces of value capture.

And so with Spread Networks' pipeline or the expensive Manhattan or New Jersey real estate devoted solely to housing servers and connections to Internet exchange points, ${ }^{7}$ we see a very material spatial fix with fixed capital dedicated to grabbing higher financial profits through microsecond competitive advantages, irrespective of the assets underlying specific financial products (i.e. whether the trade is based in McDonalds or mortgages is largely irrelevant to HFT). Railways re-administered time, literally creating new time zones, to link distinct geographies of production, circulation, and exchange. HFT re-administers geography in order to gain tiny slices of time in the sphere of exchange. These are technologies of timespace compression that, in Brenner's (1998) terms, re-scale capital accumulation in conjunction with new political forms (e.g. the railroads of state-managed imperialism, the fibre optic cables of transnational corporate capital). Here the re-scaling links monumental, persistent spatial projects like skyscrapers and satellites dishes with the fleeting time-scales of automated financial exchange.

This competition for time led to an arms race in algorithms and pipelines, to the point where, in 2010, "HFT accounted for more than $60 \%$ of all U.S. equity volume and seemed positioned to swallow the rest" (Phillips 2013). But arms races rarely end well, for armed and unarmed alike. And so on May 6, 2010 this particular fix began to crash into its limits as the Dow Jones Industrial Average lost 1000 points, about a trillion dollars in market value, in around five minutes. The Commodity Futures Trading Commission report on the so-called "Flash Crash" blames one large sell-order of S\&P 500 contracts for setting off the crash, but it reverberated so quickly because of a cascade of automated sell-order responses to that larger order and millisecond back-and-forth "hot potato" trades of position contracts between different firms' algorithms (SEC 2010).

Algorithms operating in the equities market reacted to this turmoil in the futures market by withdrawing all of their orders simultaneously, creating a massive liquidity gap which rapidly pushed shares of usually stable stocks such as Procter \& Gamble to extreme lows or extreme highs-either pennies or hundreds of thousands of dollars per share. Stocks stabilized and liquidity returned to the market over the next day, but not without leaving traders, regulators, and the general public shaken. In 2012, the crisis seemed to reappear, as Knight Capital, accounting for $17 \%$ of all trades on the New York Stock Exchange, lost control of an HFT algorithm that bought and sold US\$7 billion in shares in 45 minutes. Repairing the damage cost the company $\$ 440$ million or $40 \%$ of their valuation the day before.

These momentary crises are shocking for their potential to disrupt the broader financial sector but, for HFT insiders, it is overshadowed by a more general crisis in both the rate and mass of profit: "Average profits have fallen from about a tenth of a penny per share to a twentieth of a penny", the HFT industry made only $\$ 1$ billion in 2012 compared to $\$ 5$ billion in

\footnotetext{
7 The best example of this is the co-location services provided at 60 Hudson Street in Manhattan how trading
} firms jockey for nearby real estate, which can network with the building and gain further advantage (Miller 2013). 
2009, and about half as many HFT trades were made in 2013 compared to 2011. Knight was bought by a competitor, Getco, who revealed in 2013 that their profits had declined $90 \%$ over the previous year (Phillips 2013). The generalization of HFT technology and the geographical reorganization it facilitates means competing firms have basically erased all the "inefficiencies", which HFT was built to take advantage of in the first place. And so HFT firms are now forced to seek out new areas-social media rumours, larger bets on future market movement, insider trading-on which to take positions. The pipelines, microwave relays, and server farms are too expensive a fix to abandon, and so they will need to be repurposed to capture relative surplus value in new spaces.

Or perhaps the institutional investors will lose all faith in the technology. Or maybe it will be regulated into unprofitability. It is important to track this movement and its repercussions but for the sake of our argument, the future of HFT specifically is less important than its pioneering expansion in the annihilation of time by space. Currently these millisecond advantages are specific to financial exchanges where that level of competition is meaningful but it is not difficult to imagine this strategy becoming more broadly generalized, with resulting radical shifts in the geography of everyday life. Microwork platforms such as Amazon's Mechanical Turk or CrowdFlower, where users crowdsource the labour necessary to complete tasks broken up into minute components such as searching for text, debugging code, or doing simple math, are already supplemental, but rarely primary, income streams for the un- or underemployed, especially workers with disabilities or in areas particularly hard hit by the recent recession. And these microworkers struggle to grab tasks from those submitting them before competing microworkers-who might be a continent away with better Wi-Fi or better luck (Marvit 2014). Other microwork platforms take this model offline, with TaskRabbit allowing users to contract out mundane tasks like standing in line or picking up dry-cleaning.

One could imagine a version of The Bridge, the ad hoc San Francisco squatter's community from William Gibson's (1994) Virtual Light, overtaken by microlabourers who use the proximity of the squat to the city's Internet exchange point to outcompete desperate microlabourers in other locales or to solicit menial tasks from the gated communities on the other side of town. Such spaces, abandoned by capital but facilitating the micromobility of labour, could become techno-slums, the tenements of the 21 st century. The competition would remain in the sphere of exchange, with the permanently jobless fighting for the space that would let them sell their labour power just a moment faster than the man or woman next to them, desperately attempting to move at the speed of capital.

\subsection{The Rise of Affect Rent}

If this speculative image of microlabourers spending their days hitting refresh repeatedly to gain access to micro-contracts of semi-skilled work is carried forward, there is also the question of what these people do in their leisure time. Recuperation of labour power necessitates rest, and that rest often involves leisure. And within play we see another emergent fix: video game publishers, distributors and production studios shifting their business models towards what could be described as rentiership, in that they derive a portion of their profits from the extraction of rents from game players, rather than solely through the sale of the video game commodity. We call this "affect rent" and its rise is visible in online marketplaces attached to digital games. These marketplaces revolve around the random generation of objects whose scarcity is determined by algorithms in competitive multiplayer games like Team Fortress 2 or Counter-Strike: Global Operations. The commodities themselves take the form of cosmetic additions to the game: in the case of, say, Team Fortress 2, they are a variety of silly hats that you can dress your avatar in. Yet even in their supposed silliness, the seriousness of their existence is underlined by the fact that the Washington-based Valve Software, developer and publisher of Team Fortress 2, hired the economist (and later Greek Minister of Finance) Yanis Varoufakis in 2012 to help them manage this "hat-based" economy (Varoufakis 2012). Initially Valve was concerned about managing the valuation of these hats in the players' barter economy; but they soon introduced the ability to buy and sell these hats with real money, while collecting a mandatory $5-15 \%$ fee from every player transaction. What we see, 
then, with affect rent is the quantitative development of older spatial fixes for rent extraction: finding a new space (online gaming), commodifying it using available tools (digital rights management, a proprietary platform, and a fully enclosed marketplace) while making opting out difficult or expensive. It is not dissimilar to rent increases in dense urban areas, which reflect the relative surplus value that is imparted by proximity to cheap utilities, support services and an abundant labour supply.

Here it is important to contextualize and set apart our concept of affect rent from Marx's concept of ground rent. In chapter 37 of Capital vol. 3, Marx analyses ground rent's direct link to the labour theory of value. Ground rent is the "portion of the surplus-value produced by capital [that] falls to the share of the landowner" (Marx 1993, 751). Ground rent is produced through a very specific social relation, one between the landowners with a monopoly on the use of a piece of the earth and the capitalists, which pay ground rent to exploit that land. When the agricultural capitalist successfully wrests surplus value from their fixed and variable capital on the land (their factories and their labourers), the levy they pay to the landowner is ground rent. Marx is very clear that this social relation is, most importantly, an antagonistic one, with capitalists and rentiers struggling to assert their dominance. Because land is inherently valueless (it is, after all, not produced by human labour) the value extracted from it by the rentier is the result of relationships of violence and monopoly. If the capitalist fails to produce any surplus value on the land, what is extracted from them is not ground rent, but merely a levy or "simple" rent. Marx also notes that rent in general also serves a purpose for capital by providing a signalling function for future productive capacity. If rents drastically increase, this suggests that the productivity of capital on that land will also increase.

Ground rent then, much like all of Marx's concepts contained in the three volumes of Capital is historically specific in its scope and aim. It is not what he would describe as a bourgeois economic "eternal category" which would purport to explain rent through all historical epochs and societies. Ground rent helps Marx place rentiers, who have enjoyed a monopoly on land through a historical process tied directly to the enclosures at the dawn of the industrial revolution (Polanyi 2001), in the social relations of capitalism.

Affect rent describes a quantitatively different social relation, rather than a qualitatively new one: that between players/consumers/labourers and the owners of virtual worlds and their attendant virtual commodity marketplaces. Affect rent occurs where video game developers and virtual world owners extract value from the unpaid labour and play of those who create digital commodities, whose sole use value is affective ${ }^{8}$ (Moore 2011). These in-game commodities are then able to be alienated by the player for any price (or bartered/gifted) on an open marketplace. The prospective buyer pays the commodity owner's market price, which includes a transaction fee (the rent itself) to the in-game marketplace owner to enjoy the affective qualities of objects, whatever form they may take. The game and the marketplace itself, make up the digital "land" that video game companies can demand rents from. They set the terms of commodity creation-how much time is required to play to get commodities; how commodities are created in-game-and the probabilities of the commodities being randomly rewarded. In this way the players are both consumers and labourers: their play produces the commodity which is sold to other players for real money-with Valve extracting a rent-the proceeds of which they could then use to buy another commodity. Inside this domain of almost total control, the digital rentier then profits off the exchange of commodities between players.

Affect rent is thus distinct quantitatively from ground rent in a number of ways. Most importantly, it is not based around a monopoly over already existing land, which is inherently valueless. Instead virtual worlds themselves have been crafted entirely through human labour, relying on human-made networked infrastructures. While we find the concept of affect rent most visible in digital games and virtual worlds, we see this this fix is generalizable across acts of communication, space and forms of social life. That play itself is subject to it just shows how malleable life is to capital. In a sense this is a logical extension of the 8 The term "affect" is here used in reference to the expressive, non-material qualities of objects. It is an ontologi-
cal property that in absence of a being to interpret it lacks any function (DeLanda 2006). 
tendencies that Lawrence Grossberg $(1987 ; 1996)$ has theorized. Affect rent is a function of the "affective economies" he described that have existed in and around mass media for decades. What is new is that proprietary software platforms have inserted themselves between producers and consumers while extracting rents between all kinds of transactions, ushering in an age of what some have called "platform capitalism" (Lobo 2014).

What is taking place is a kind of real subsumption of play into labour, through the commodification of the play act itself to the production of surplus value. ${ }^{9}$ For Marx, formal subsumption is the incorporation of pre-capitalist forms of production into capitalism while real subsumption entails the transformation of that production for increased relative surplus value, achieved through management techniques and technologies that increase productivity (endnotes 2010; Murray 2004). Selling games to consumers formally incorporated play, but that play is really subsumed when it is itself shaped to meet the needs of capitalist production.

One way in which digital games are subject to real subsumption is through what Mia Consalvo (2009) calls "paratextual industries" (drawing on Genette's [1997] concept) that arise around the video game industry. They create new commodities, markets and consumers, which rely on the original game as source material. Consalvo examines these industries through their production of printed strategy guides, cheat sections in consumer magazines, and pieces of hardware that enables players to cheat and gain advantage in video games. While Consalvo's concept of the paratextual industry provides a way to describe this industry and phenomenon, the spatial relationship that is formed is left unexplored. It's worth thinking about where these paratextual industries arise, and what new paratextual industries will look like as capital creates new digital spaces to bypass current limits. These limits were clearly visible in the video game industry crashes of 1977 and 1983 as crises of underconsumption alongside over-valued assets (Wolf 2012).

One can interpret the creation of paratextual industries as one fix to a limit: the video game industry's strict reliance on only selling the video game commodity. ${ }^{10}$ The original commodity becomes the basis on which to sell a variety of other commodities, not dissimilar to the growth of merchandising associated with Hollywood cinema. Yet such fixes focused on merchandising paratexts cannot last forever, as competition increasingly narrows such advantages in the marketplace. As a result the video game industry has increasingly turned to some of the same tactics that broadcast media did to develop the audience commodity. This is achieved by transitioning video games from a commodity that contained in its sale price the requisite surplus value to realize profit into a medium through which players as audiences are commodified for advertisers. This is best exemplified by the transition to so-called "freeto-play" business models that developers such as Zynga pioneered (Gobry 2011). These free-to-play games cost nothing to initially download and play, but always incorporate microtransactions that give the player new abilities or in-game currency to spend on in-game objects and abilities. Recall that for Smythe (1977) the content of the television or radio program is what drew in the audience for the real labour that was to be done: watching advertisements. In the same way free-to-play games do the same thing, offering an experience that has no initial cost but in return requires the player to often subject themselves to a variety of advertisements (textual, in-game, or video).

In addition to creating a new space for the audience commodity (which is more of a function of the previous spatial fix we described, the primitive accumulation of time) playing games itself becomes the source of labour required to develop a particularly unique kind of digital commodity. These commodities in digital games take on two distinct use values: the

\footnotetext{
${ }^{9}$ Here we use a specifically historical conception of play rather than a formal or ideal one. Play is best understood in modern society as the leisure act that exists in relation to the way in which society structures and reproduces itself. As Silverman and Simon (2009) say, "in modernity, one has to play because one works, and play in this sense, has no significant meaning outside its relationship to work" (354). At the same time it also exists in direct relationship with a variety of macro and micro assemblages. For more see Taylor (2006) and Joseph and Knuttila (2014).

10 See Dyer-Witheford and de Peuter (2009) for more on the distinct political economy of video games, which shares in common many concerns associated with other media industries like television and film, while also having very unique characteristics.
} 
first is that which imparts an advantage in the game and the second is purely aesthetic. Sometimes, in the cases of online virtual worlds and massively multiplayer games the players create the commodities themselves (Pearce 2006). This can develop into odd and innovative systems of reciprocity and reward, like the "Dragon Kill Points System" developed by large groups of players in Everquest Online (Silverman and Simon 2009). More often, however, commodities are created by fiat of the company that operates and owns the game. The object is bought directly from the developer, or created through an act labour and play, sometimes called "playbour" or play-labour (Kücklich 2005; Lund 2014), that is required by the developer.

While this method of in-game commodity production was pioneered in massively multiplayer online games, it has spread out to free-to-play games like those created by Zynga, and other genres such as first person shooters (Counter-Strike: Global Offensive) or multiplayer action and strategy games (Defence of the Ancients 2). Valve is a market leader in the latter two genres. For a number of years now Valve has experimented heavily with their Steam Community Marketplace, which mediates the transactions of all games published by Valve, as well as some that aren't. While many games like World of Warcraft or EVE: Online have marketplaces, what makes the Steam Community Marketplace special is that it incorporates real money transfer. ${ }^{11}$ Not only can objects be bartered with other in-game objects, but they can be sold using US dollars and a variety of other major currencies. This is made possible because of Steam's origin as a digital distribution platform for the sale of digital games. To buy these games people can either directly purchase them with their credit card or deposit money directly into their "Steam Wallet". This digital wallet is what allowed for the introduction of digital commodities in game to be sold for real money, because the wallet allows for debiting and crediting of the account. With the ability of players to pay each other for their digital commodities it also meant that these transactions could now be subject to a mandatory fee, or as we argue, an affect rent, set betweenfive and fifteen percent of the sale price. Maybe most importantly, regular users of Steam can't take money out of the Steam Wallet, turning their earnings into a form of company scrip.

The result of this kind of commodity creation is production that is conducted entirely inside digital spaces themselves, with almost no connection to what might have once been traditionally considered productive labour. Yet Valve captures this value all the same. In this case it's a paratextual industry that arises inside the object of the game. Spatially, it is a move away from capturing surplus value in the video game production studio towards capturing surplus value in the network of players. In this way it has shifted the spatial relationships that once defined the video game industry. And it is not limited just to the paratexts of games and play: this fix exists in the production of digital commodities in all sectors of life. Currently social media platforms like Facebook sell "stickers" and other items that can be sent to other users. The production of digital commodities directly linked to the production of affect is at the core of this spatial fix. They can be as simple as digital stickers or colourful patterns for digital items or as complex as deeply personal letters. In the process, if these digital commodities can be traded and sold amongst users, the fees that the service and platform holders extract generalize this kind of rent. ${ }^{12}$

Thinking of paratextual items as primarily linked to affect helps conceive of the shift in a wider context, where the production and consumption of affect increasingly takes on economic importance. Setting it apart from the previous spatial fix, the primitive accumulation of time, the value extracted isn't so much the attention of the consumer-as in the free lunch

\footnotetext{
${ }^{11}$ The creation of digital property in games and virtual worlds is storied and quite complex at times. Much as land was once the most important asset for early capitalism (Piketty and Zucman 2014), digital land in games like Ultima Online and in Second Life was especially important. See Dibbell $(2003 ; 2009)$ for an early take on the emergence of this.

${ }^{12}$ The latter is an extreme example, based in part on Spike Jonze's 2013 film Her. In it the protagonist, Theodore Twombly, spends his days working in a sleek downtown LA office ghostwriting personal letters. In so doing the customers outsource the production of affect entirely to Twombly, whose final product is a letter that he hand mails when he leaves the office at the end of the work day.
} 
model proposed by Smythe (1977) —but in the rent taken from consumers selling commodities produced for almost nothing, whose only use value is affective.

The rise of affect rent as a result of the real subsumption of play means that the video game industry continues to grow, especially in in its free-to-play and fully marketised forms. These companies, considered by many as the industries on the cutting edge of capitalism for their relatively high wages and creative work, have quickly become one of the few kinds of businesses that cities pursue with industrial and cultural policy of various kinds, but almost always with the aims of protectionist cultural nationalism or job creation (Joseph 2013).

Alongside these more seemingly prosaic concerns is the likelihood of the multiplication of crisis points in these (mostly unregulated) game-based marketplaces as they extend beyond the small corners of the Web they currently reside on. Fully subsumed play could become a larger and larger part of the contemporary economy, with labour forces dedicated entirely to creating or capturing in-game commodities to sell to other players at a profit. This already happens, to various extents, with the existence of professional World of Warcraft gold farmers in China, working twelve to fourteen hour days in offices filled with computers running the latest version of the virtual world (Dyer-Witheford and de Peuter 2009). The same cycles and pressures that are created in the pursuit of surplus value are replicated in these new forms of labour: relative surplus gained through mechanization and absolute surplus gained through the extension of the working day. At the other end of digital production we see a possible crisis in the making as the market is flooded with these cheap, likely useless commodities, further reducing their prices. Just as tied up in this is the increasing reliance of digital games on advertising revenue and data collection. In the case of the game streaming site Twitch.tv, steamers who qualify as "partners" can earn money much the way popular YouTube stars do (Twitch 2015; Walker 2014). In such cases the contracts of professional e-sports players and streamers often depends on the overall ad revenues of such platforms (Taylor 2012). If the bottom falls out of these monetization schemes-if a crisis occurs-the house of cards that holds up precarious digital labour and play could come tumbling down. In the process these digital workers would likely have no recourse due to the elaborate end-user license agreements they are forced to sign to play, while platform capitalists could maintain their positions if they can play the same game that rentiers of the past did: revalue their "land" to speculate on lowered productivity and devalued capital, and gouge the cyber-proletariat what still relies on making their living through digital play.

\section{Conclusions and Directions for Future Research}

Our goal has been to outline how digital communication technologies give rise to new kinds of spatial fixes. Our examples-the primitive accumulation of time, the annihilation of time by space and affect rent-showcase new, digital assemblages brought about by the intermixing of technology, capitalism and ongoing crises in the wider social production of human existence. Digital spaces are experimental venues for new accumulation regimes, where fixes attempted elsewhere are refashioned, redeveloped, and redeployed. Digital labour is still labour-even if it is not understood as such by the labourer-and thus is the source of value. What is new is that digital technologies create new methods to steal tiny slivers of working time from the labourer, exchange the value produced by labour quicker than other capitalists, and extract rent from the very pleasure taken in digital communities.

Our three examples do not exhaust the potential options for digital spatial fixes. Surely others already exist or will develop. Rather, our analysis of these examples functions as a methodological guide and a conceptual foundation for linking Marxian approaches to economic geography and digital media. In his earliest theorization of the concept, Harvey (1981) also explored three general examples of spatial fixes: exporting capital to new markets of consumers, exporting capital for new, more profitable production, or expanding the proletariat through primitive accumulation. Others built and revised these concepts and extended them into new social fields. Wright's (2001) analysis of development in Ciudad Juarez showed a fix centred not just on border factories but also on the reproduction of gendered social relations. Brenner (1998) focused not on individual fixes but how they connect together to re-scale cap- 
ital accumulation and circulation in the wake of global crises. With these theory-building projects in mind, we hope to encourage digital media research that is mindful of the critical function of spatial fixes, as well as research in economic geography that attends to digital materials. This will always require precise documentation and explanation of economic crises and their movement between digital and physical spaces. By way of conclusion, we offer some possible directions for future research that can build on the methodological guides and conceptual foundations provided here. Because we have thus far focused mainly on the spatial dimensions of digital capitalism, these sketches of future research directions focus on the how the remaking of space necessarily remakes time. Celebrations of digital capitalism as weightless and spaceless also laud a new era of timeless and instantaneous circulation, where value is both preserved perfectly and transmitted without delay (Huws 1999). But just as digital media have a specific economic geography, so too do they emerge from and produce in turn a particular ordering of time.

Temporal patterns of over-accumulation are present in Harvey's work from early on: There is a persistent focus on the temporal delays introduced or overcome by fixed capital projects, and his second-cut theory of crisis explored in Limits to Capital (1982) explained the credit system as a sort of temporal fix that establishes a socially necessary turnover time to regulate various capitals' turnover time and displace current accumulation crises into the future. These earlier remarks on time often merely add the effects of time to those of space and do not display either the elegant dialectical reasoning or historical specificity of Harvey's spatial theories (Jessop 2006). Later work such as The New Imperialism (2003) rechristens the spatial fix as the "spatio-temporal fix" and explains the capitalist restructuring of spatial relations as necessarily a restructuring of temporal ones. There, Harvey is especially interested in how capitalist firms and states invest surplus capital in "physical and social infrastructures" that take many years to bear a return, thus staving off over-accumulation in the present while remaking a region in a way that will maximize future accumulation (2003, 87-137). These massive investments have many smaller spatio-temporal components: logistical projects that bring the timelines of production and exchange into alignment, the displacement of current crises in one geography into the future of another, and periodic "switching crises" that shift surplus capital from primary to secondary or tertiary sectors and devalue those sectors for the long-term health of the system. Spatial fixes are necessarily temporal ones. And so the capitalist restructuring of digital spaces is necessarily a reordering of the tempo of accumulation, in an attempt to displace, stall, or stave off the timeline of crisis.

Building on Harvey's triple meaning of "fix" as a geographic solution to accumulation crises, a blockage that eventually leads to future crises, and an addiction to the process, we hope our description of digital spatial fixes prompts further investigation into the relationship between new digital accumulation regimes and older temporal patterns of crisis. Matthew Crain's (2014) analysis of the dotcom crash shows how the 1990s Get Big Fast strategy to accumulate as much market share and user attention as possible as quickly as possible relied on risk capital funding that ignored traditional metrics like "negative cashflow" in favour of "marketing based asset-valuation models" such as Web traffic statistics. Future financial gains were prioritized over quarter-to-quarter revenue and a whole chain of venture-backed online advertising firms grew to support this future orientation-and each other-by designing, rating, and selling audience attention. The end result was a feedback loop between online advertising and risk capital that inflated the dotcoms beyond any reasonable valuation. Many features of this system remain in operation today. But a massive firm like Google effectively integrates the functions of selling, placing, rating and, in some cases, generating advertisements online (Bermejo 2009), both through in-house technological developments and the acquisition of firms (e.g. dMarc, DoubleClick, Applied Semantics) that previously worked at different parts of the advertising value chain. This would appear to be a classic case of capital concentration and it may eliminate opportunities for risk capital to insert itself into the moments of circulation time between different portions of the online advertising economy. But does this prevent the over-accumulation of capital in the online advertising economy, or merely localize it? 
Capitalist spaces play many tricks with time, but it is the control and capture of labour time, which is of the highest priority. The economic geography of digital media connects multiple accumulation regimes with differing organizational and technological approaches to labour time, arrayed together to maintain the exploitation of different regimes and the overall profit rate. This is a global problem and we are hardly the first to note the pressing need to map the circulation of capital between digital industries with heavy fixed capital requirements and hyper-exploited labourers elsewhere in the world. Ross (2013), for example, calls the high-skilled digital labourers of the US and Europe and the low-paid factory workers of Eastern and Southeastern Asia "two ends of the digital chain gang": One end bleeding over the assembly line products that the other end uses to power 100-hour work weeks, neither with much control over a heavily automated labour process. Caffentzis (2013) notes that this contemporary manifestation of the "transformation problem" is not just a theoretical concern of Marxology, but also a crucial problem of development. Profits in industries with high fixed capital costs, where commodity prices are often greater than their values, rely on profits from labour-intensive industries, where commodity prices are often lower than their values, that feed those "developed" economies raw materials and means of production. But where do digital spaces and times fit into this equation? Ross' image assumes geographical separation but what about Foxconn workers who spend their leisure time on Chinese social networking site Weibo? Do they sit at both ends of the chain gang at different times of the working day? And of course, exploitation is not just for hardware production. Facebook's massive advertising revenues are made possible by content moderators cleaning Facebook pages of objectionable material and, as explored above, by the industrialized impersonation of "genuine" social interaction by spammers who inflate traffic metrics. The Philippines is a centre of activity for both (e.g. Chen 2014; Clark 2015). A slowdown in these spaces of exploitation would surely slow Facebook's profit rate, but how much? And what is the threshold of tolerance before a fix is sought?

It must also not escape notice that the capitalists and skilled labourers designing the digital spatial fixes explored above are themselves enmeshed in a more traditional fix that Harvey (1989) and his students (e.g. Smith 2002) have long explored: The reinvestment of surplus capital into urban centres, reversing decades of state-aided capital flight from cities to majority-white suburbs, powering a gentrification wave, and providing a long-term outlet for over-accumulated capital. This shift from a managerial urbanism where cities acted as local outposts of the Keynesian welfare state to an entrepreneurial urbanism where cities compete to recruit producers, mass culture events, and gentrifiers has been accompanied by a new boosterism celebrating the "creative class". In Florida's (2003) account, these bohemian urbanites, many of them working in technology, are the leading edge of contemporary capitalism and are attracted to "creative cities" whose diverse cultural offerings allow the creative class to unplug and provide the raw, cultural materials which these skilled labourers craft into immaterial commodities.

The 2008 crash and the dot-com bubble before it would seem to have disproved the common sense that creative sectors would save postindustrial economies, especially in urban centres. But Florida (2011) used the crisis to retrench his theory, explicitly linking it with Harvey's spatial fix argument by asserting that the real estate crisis signalled the failure of the postwar suburban spatial fix and the need for a new one focused on urban infrastructure, digital technologies, and flexible working hours. But by focusing on the spatial fix only as a geographic solution to past crises and not as a cause of future crises or the addiction to repeat them or expand beyond them, Florida inadvertently proves that the push to reorganize urban space for technology workers and related creatives is the latest, most prominent example of entrepreneurial cities desperate for a fix.

Peck (2005) argues that creative cities placemaking may just be a post-facto endorsement of already-ongoing gentrification, making real estate and retail investment appear as an investment in productive capacity. But Harvey's (2003) approach points to another possible interpretation: that these different fixes are evidence of a switching crisis in action. Technology firms flush with cash may be, with the help of municipal governments, building buildings because they want to switch capital out of digital accumulation circuits and into dependable, 
long-term real estate investments. One example could be SalesForce's new skyscraper at the centre of San Francisco's Transbay redevelopment plan (Roose 2014). Another could be the fight between Google and Linkedln to redevelop North Bayshore (Donato-Weinstein 2015). These developments may signal capital's recognition that certain digital spatial fixes have reached their limits, that there is a need to shift the accumulated surplus from the shortterm horizons of the Web (e.g., Google's $\$ 59$ billion in cash reserves were, in 2013, larger than those of the US) into the fixity of roads and buildings.

It is important to trace these links between digital and brick-and-mortar capitalist geographies because of the real danger that digital labour will only be seen from the perspective of those like Florida today or $\mathrm{MCl}$ in the 1990s, who reduce labour to immaterial categories like "creativity" and mystify the processes at work. Florida's use of the "fix" terminology as a solution to new problems but not as a function of an addiction to an ongoing cycle is thus not an individual oversight or error in theoretical orthodoxy, but a symptom of a larger problem. A problem where the digital economy is breathlessly treated as a sharp break with the historical landscape of labour (as in the theories of the network society, post-industrial society, postfordism, etc) and, in extreme cases, with time and space themselves.

But digital geographies are always material: based in the exploitation of living labour and the concretization in the dead labour of machines and circuit boards. The digital vistas explored by players in World of Warcraft and the prosaic Facebook viewed while riding the bus are made possible only through the intense energy consumption of the data centres which double as "factories" for the production of value in the 21st century. For example, in 2009 it was estimated that World of Warcraft relied on over twenty thousand individual servers, all provided by AT\&T (Miller 2009). And it should not be forgotten that it is both the outdated computers from these data centres as well as the computers the games are played on that end up in e-waste dumps around the globe, their precious metals melted down using medieval style smelting techniques by local slum dwellers (Greaves 2011). That capitalism is based on exploitation is not only a political proposition, but also an empirical demand that new forms of exploitation and their interaction with older models of accumulation be rigorously confronted and mapped across bodies and bits, time and space.

\section{References}

Ammari, Tawfiq, Priya Kumar, Cliff Lampe and Sarita Y. Schoenebeck. 2015. Managing Children's Online Identities: How Parents Decide what to Disclose about their Children Online. Proceedings of the ACM Conference on Human Factors in Computing Systems (CHI '15). Seoul, Korea.

Beniger, James. 1989. The Control Revolution: Technological and Economic Origins of the Information Society. Cambridge, MA: Harvard University Press.

Bermejo, Fernando. 2009. Audience Manufacture in Historical Perspective: From Broadcasting to Google. New Media \& Society 11 (1\&2): 133-154.

boyd, danah. 2014. It's Complicated: The Social Lives of Networked Teens. New Haven: Yale University Press.

Brenner, Neil. 1998. Between Fixity and Motion: Accumulation, Territorial Organization and the Historical Geography of Spatial Scales. Environment and Planning D 16 (1998): 459-482.

Burt, Ronald. 2012. Structural Holes: The Social Structure of Competition. Reprint edition. Cambridge, MA: Harvard University Press.

Caffentzis, George. 2007. Crystals and analytic engines: Historical and conceptual preliminaries to a New Theory of Machines. Ephemera 7 (1): 24-45.

Caffentzis, George. 2013. On Africa and Self-reproducing Automata. In In Letters of Blood and Fire: Work, Machines, and the Crisis of Capitalism, 127-138. Oakland: PM Press.

Castells, Manuel. 2009. The Rise of the Network Society: The Information Age: Economy, Society, and Culture Volume I. 2nd Edition. Hoboken, NJ: Wiley-Blackwell.

Chandler, Alfred. 1993. The Visible Hand: The Managerial Revolution in American Business. Cambridge, MA: Belknap Press.

Chen, Adrian. 2014. The Labourers Who Keep Dick Pics and Beheadings Out of Your Facebook Feed. Wired. Accessed May 1, 2015. http://www.wired.com/2014/10/content-moderation/ - x. 
Clark, Doug Bock. 2015. The Bot Bubble: Click Farms Have Inflated Social Media Currency. The New Republic. Accessed May 1, 2015. http://www.newrepublic.com/article/121551/bot-bubble-clickfarms-have-inflated-social-media-currency.

Crain, Matthew. 2014. Financial Markets and Online Advertising: Reevaluating the Dotcom Investment Bubble. Information, Communication \& Society 17 (3): 371-384.

Davis, David Brion. 2006. Challenging the Boundaries of Slavery. Cambridge, MA: Harvard University Press.

De Angelis, Massimo. 2001. Marx and Primitive Accumulation: The Continuous Character of Capital's 'Enclosures'. The Commoner 2 (September). http://www.thecommoner.org.

DeLanda, Manuel. 2011. A New Philosophy of Society: Assemblage Theory and Social Complexity. London: Continuum.

Deleuze, Gilles. 1992. Postscript on the Societies of Control. October 59 (Winter): 3-7.

Dibbell, Julian. 2003. The Unreal Estate Boom. Wired Magazine, January.

Dibbell, Julian. 2009. The Chinese Game Room: Play, Productivity and Computing at Their Limits. Artifact 2 (2): 82-87.

Donato-Weinstein, Nathan. 2015. How LinkedIn Won Over Mountain View and Google Stumbled. Silicon Valley Business Journal. Accessed May 6, 2015. http://www.bizjournals.com/sanjose/news/2015/05/06/how-linkedin-won-over-mountain-view-andgoogle.html?page=all

Dyer-Witheford, Nick. 1999. Cyber-Marx: Circuits of Struggle in High Technology Capitalism. Champaign, Illinois: University of Illinois Press.

Dyer-Witheford, Nick. 2015. Cyber-Proletariat: Global Labour in the Digital Vortex. London: Pluto Press.

Dyer-Witheford, Nick, and Greig de Peuter. 2009. Games of Empire: Global Capitalism and Videogames. Electronic Mediations. Minneapolis: University of Minnesota Press.

Endnotes. 2010. The History of Subsumption. Endnotes 2 (April).

Florida, Richard. 2003. The Rise of the Creative Class: And How It's Transforming Work, Leisure, Community, and Everyday Life. New York: Basic Books.

Florida, Richard. 2011. The Great Reset: How the Post-Crash Economy Will Change the Way We Live and Work. New York: HarperBusiness.

Fuchs, Christian. 2010. Labour in Informational Capitalism and on the Internet. The Information Society 26 (3): 179-96.

Florida, Richard. 2012. The Political Economy of Privacy on Facebook. Television \& New Media 13 (2): 139-59.

Genette, Gerard. 1997. Paratexts: Thresholds of Interpretation. Cambridge University Press.

Gerlitz, Carolin and Anne Helmond. 2013. The Like Economy: Social Buttons and the Data-Intensive Web. New Media \& Society 15 (8): 1348-65.

Gibson, William. 1994. Virtual Light. Reissue edition. New York: Spectra.

Glassman, Jim. 2006. Primitive accumulation, Accumulation by Dispossession, Accumulation by 'Extra-economic' Means. Progress in Human Geography 30 (5): 608-625.

Gobry, Pascal-Emmanuel. 2014. How Zynga Makes Money. Business Insider. Accessed September 3. http://www.businessinsider.com/zynga-revenue-analysis-2011-9.

Golumbia, David. 2013. High-Frequency Trading: Networks of Wealth and the Concentration of Power. Social Semiotics 23 (2): 278-99.

Graham, Mark. 2013. Geography/internet: Ethereal Alternate Dimensions of Cyberspace or Grounded Augmented Realities? The Geographical Journal 179 (2): 177-82.

Greaves, Matthew. 2011. The iPad and Its Secrets. MA thesis. York University.

Griffiths, leuan. 1986. The Scramble for Africa: Inherited Political Boundaries. The Geographical Journal 152 (2): 204-16.

Grossberg, Laurance. 1987. The In-Difference of Television. Screen 28 (2): 28-46.

Grossberg, Laurance. 1996. History, Politics and Postmodernism: Stuart Hall and Cultural Studies. In Stuart Hall: Critical Dialogues in Cultural Studies, edited by Stuart Hall, David Morley and Gangxin Chen, 151-173. Comedia. London: Routledge.

Habermas, Jurgen. 1991. The Structural Transformation of the Public Sphere: An Inquiry into a Category of Bourgeois Society. Studies in Contemporary German Social Thought. Cambridge, MA: MIT Press.

Hafner, Katie. 1994. Internet Pioneer Vinton Cerf Has the Midas Touch. Austin American Statesman. Hardt, Michael, and Antonio Negri. 2001. Empire. Cambridge, MA: Harvard University Press. 
Harvey, David. 1981. The Spatial Fix-Hegel, von Thunen, and Marx. Antipode 13 (3): 1-12.

Harvey, David. 1982. The Limits to Capital. Chicago: University of Chicago Press.

Harvey, David. 1989. From Managerialism to Entrepreneurialism: The Transformation in Urban Governance in Late Capitalism. Geografiska Annaler. Series B, Human Geography 71 (1): 3-17.

Harvey, David. 2001. Globalization and the Spatial Fix. Geographische Revue 2 (3): 23-31.

Harvey, David. 2003. The New Imperialism. Oxford: Oxford University Press.

Herod, Andrew. 2009. Geographies of Globalization: A Critical Introduction. Hoboken, NJ: WileyBlackwell.

Horkheimer, Max, and Theodor Adorno. 2007. The Culture Industry. In Dialectic of Enlightenment, edited by Schmid Noerr. Redwood City, CA: Stanford University Press.

Huws, Ursula. 1999. Material World: The Myth of the Weightless Economy. Socialist Register 35: 2855.

Jessop, Bob. 2006. Spatial Fixes, Temporal Fixes, and Spatio-temporal Fixes. In David Harvey: A Critical Reader, edited by Noel Castree and Derek Gregory, 142-66. Oxford: Blackwell.

Jessop, Bob. 2013. Revisiting the Regulation Approach: Critical Reflections on the Contradictions, Dilemmas, Fixes and Crisis Dynamics of Growth Regimes. Capital \& Class 37 (1): 5-24.

Joseph, Daniel. 2013. The Toronto Indies: Some Assemblage Required. ...Loading, Indie, Eh? 7 (11). http://journals.sfu.ca/loading/index.php/loading/article/view/123.

Joseph, Daniel and Lee Knuttila. 2013. Single Player / Multiplayer. In Routledge Companion to Video Game Studies, 211-18. London: Routledge Press.

Kücklich, Julian. 2005. Precarious Playbour: Modders and the Digital Games Industry. The Fibreculture Journal 5. http://five.fibreculturejournal.org/fcj-025-precarious-playbour-modders-andthe-digital-games-industry/.

Lobo, Sascha. 2014. S.P.O.N. - Die Mensch-Maschine: Auf Dem Weg in Die Dumpinghölle. Spiegel Online. http://www.spiegel.de/netzwelt/netzpolitik/sascha-lobo-sharing-economy-wie-bei-uber-istplattform-kapitalismus-a-989584.html.

Lowrey, Anne. 2014. If a Bubble Bursts in Palo Alto, Does it Make a Sound? The New York Times. Accessed November 13, 2014: http://www.nytimes.com/2014/04/27/magazine/if-a-bubble-bursts-inpalo-alto-does-it-make-a-sound.html? $r=0$.

Lund, Arwid. 2014. Playing, Gaming, Working and Labouring: Framing the Concepts and Relations. tripleC: Communication, Capitalism \& Critique 12 (2): 735-801.

Luxton, Meg, and Kate Bezanson, eds. 2006. Social Reproduction: Feminist Political Economy Challenges Neo-Liberalism. Montreal: McGill-Queen's University Press.

Marvit, Moshe Z. 2014. How Crowdworkers Became the Ghosts in the Digital Machine. The Nation. http://www.thenation.com/article/178241/how-crowdworkers-became-ghosts-digital-machine.

Marx, Karl. 1953. Grundrisse der Kritik der Politischen Ökonomie. MECW Vol. 42. Berlin: Dietz-Verlag. Accessed March 16, 2015. http://kulturkritik.net/systematik/philosophie/mew/index.php?bd=42\&pg=538.

Marx, Karl. 1990. Capital: A Critique of Political Economy. Translated by Ben Fowkes. Penguin Classics. Vol. One. Penguin Books in association with New Left Review.

Marx, Karl. 1993. Capital: A Critique of Political Economy. Translated by David Fernbach. Penguin Classics. Vol. Three. Penguin Books in association with New Left Review.

Marx, Karl. 1993a. Grundrisse: Outlines of the Critique of Political Economy. Translated by Martin Nicolaus. Reprint edition. Penguin Classic.

Mattelart, Armand. 2000. Networking the World, 1794-2000. Minneapolis: University of Minnesota Press.

McLuhan, Marshall. 1994. Understanding Media: The Extensions of Man. revised. MIT Press.

McLuhan, Marshall. 2008. The Mechanical Bride: Folklore of Industrial Man. Berkeley, CA: Ginko Press.

Meehan, Eileen. 1993. Commodity Audience, Actual Audience. The Blindspot Debate. In Illuminating the Blindspots: Essays Honoring Dallas W. Smythe, eds. Janet Wasko, Vincent Mosco and Manjunath Pendakur, 378-97. Norwood NJ: Ablex.

Meikle, Scott. 1991. History of Philosophy: The Metaphysics of Substance in Marx. In The Cambridge Companion to Marx, edited by Carver and Terrell, 296-319. Cambridge, UK: Cambridge University Press.

Mezzadra, Sandro, and Brett Neilson. 2008. Border as Method, Or, the Multiplication of Labour. European Institute for Progressive Cultural Policies 3. 
Michalopoulos, Stelios and Elias Papaioannou. 2011. The Long-Run Effects of the Scramble for Africa. Working Paper 17620. National Bureau of Economic Research. http://www.nber.org/papers/w17620.

Miller, Rich. 2013. Major Expansion for Telx at 60 Hudson Street. Data Center Knowledge. Accessed September 3, 2015. http://www.datacenterknowledge.com/archives/2013/09/24/major-expansionfor-telx-at-60-hudson-street/.

Miller, Rich. 2015b. Virtual Goods and the Cost of Infrastructure. Data Center Knowledge. Accessed May 11, 2015. http://www.datacenterknowledge.com/archives/2009/11/02/virtual-goods-and-thecost-of-infrastructure/.

Moore, Christopher. 2011. Hats of Affect: A Study of Affect, Achievements and Hats in Team Fortress 2. Game Studies 11 (1).

Morozov, Evgeny. 2012. The Net Delusion: The Dark Side of Internet Freedom. New York: PublicAffairs.

Mosco, Vincent. 2005. The Digital Sublime: Myth, Power and Cyberspace. Cambridge, MA: MIT Press.

Mosco, Vincent. 2009. The Political Economy of Communication. Thousand Oaks, CA: Sage Publications.

Moulier-Boutang, Yann. 2012. Cognitive Capitalism. Cambridge, UK: Polity Press.

Murray, Patrick. 2004. The Social and Material Transformation of Production by Capital: Formal and Real Subsumption in Capital, Volume 1. In The Constitution of Capital: Essays on Volume 1 of Marx's Capital, edited by Riccardo Bellofiore and Nicola Taylor, 243-73. London: Palgrave Macmillan.

Nixon, Brice. 2014. Toward a Political Economy of 'Audience Labour' in the Digital Era. tripleC: Communication, Capitalism \& Critique 12 (2): 713-34.

Onstad, Eric. 2013. Lasers, Microwave Deployed in High-Speed Trading Arms Race. Reuters. http://www.reuters.com/article/2013/05/01/us-highfrequency-microwaveidUSBRE9400L920130501.

Peck, Jamie. 2005. Struggling with the Creative Class. International Journal of Urban and Regional Research 29 (4): 740-770.

Pearce, Celia. 2006. Productive Play: Game Culture From the Bottom Up. Games and Culture 1.1 (January): 17-24.

Phillips, Matthew. 2013. How the Robots Lost: High-Frequency Trading's Rise and Fall. BusinessWeek: Technology. http://www.businessweek.com/articles/2013-06-06/how-the-robots-losthigh-frequency-tradings-rise-and-fall - p1.

Piketty, Thomas, and Gabriel Zucman. 2014. Capital Is Back: Wealth-Income Ratios in Rich Countries 1700-2010. Quarterly Journal of Economics.

Portwood-Stacer, Laura. 2014. Care Work and the Stakes of Social Media Refusal. New Criticals. http://www.newcriticals.com/care-work-and-the-stakes-of-social-media-refusal.

Rigi, Jakob. 2014. Foundations of a Marxist Theory of the Political Economy of Information: Trade Secrets and Intellectual Property, and the Production of Relative Surplus Value and the Extraction of Rent-Tribute. tripleC: Communication, Capitalism \& Critique 12 (2): 909-36.

Roose, Kevin. 2014. The Tech Sector's New, Urban Aesthetic. New York Magazine. Accessed May 2015. http://nymag.com/daily/intelligencer/2014/05/tech-sectors-new-urban-aesthetic.html.

Ross, Andrew. 2013. In Search of the Lost Paycheck. In Digital Labour: The Internet as Playground and Factory, edited by Trebor Scholz,13-32. Routledge Press: New York.

Sassen, Saskia. 1999. Losing Control? The State and the New Geography of Power. Global Dialogue $1(1): 78-88$.

Sassen, Saskia. 2001. The Global City: New York, London, Tokyo. 2 edn. Princeton, NJ: Princeton University Press.

Sassen, Saskia. 2009. Incompleteness and the Possibility of Making. Cultural Dynamics 21 (3): 22754.

Sassen, Saskia. 2014. Expulsions: Brutality and Complexity in the Global Economy. Cambridge, MA: Harvard University Press. http://site.ebrary.com/lib/alltitles/docDetail.action?docID=10872347.

Scott, John. 2012. Social Network Analysis. 3 edn. Los Angeles: Sage Publications.

Silverman, Mark, and Bart Simon. 2009. Discipline and Dragon Kill Points in the Online Power Game. Games and Culture 4 (4): 353-78.

Smith, Neil. 2002. New Globalism, New Urbanism: Gentrification as Global Urban Strategy. Antipode 34 (3): 427-50. 
Smythe, Dallas W. 1977. Communications: Blindspot of Western Marxism. Canadian Journal of Political and Social Theory 1 (3): 1-28.

Steiner, Christopher. 2014. Wall Street's Speed War. Forbes. Accessed September 3, 2015. http://www.forbes.com/forbes/2010/0927/outfront-netscape-jim-barksdale-daniel-spivey-wall-streetspeed-war.html.

Talbot, David. 2014. In Developing Countries, Google and Facebook Already Defy Net Neutrality. MIT Technology Review. http://www.technologyreview.com/news/523736/around-the-world-netneutrality-is-not-a-reality/.

Taylor, T.L. 2012. Raising the Stakes: E-Sports and the Professionalization of Computer Gaming. Cambridge, MA: MIT Press.

Thomas, Sue. 2006. The End of Cyberspace and Other Surprises. Convergence 12 (4): 383-391.

Twitch. 2015. Twitch Advertising. Twitch Advertising. Accessed May 11. http://twitchadvertising.tv.

U.S. Securities Exchange Commission. 2010. Findings Regarding the Market Events of May 6, 2010: Report to the Staffs of the CFTC and SEC to the Joint Advisory Committee on Emerging Regulatory Issues. U.S. Securities Exchange Commission.

Varoufakis, Yanis. 2012. It All Began with a Strange E-Mail. Accessed September 3, 2015. http://blogs.valvesoftware.com/economics/it-all-began-with-a-strange-email/.

Vranica, Suzanne. 2014. A 'Crisis' in Online Ads: One-Third of Traffic Is Bogus. Wall Street Journal, March 23, sec. Business. http://online.wsj.com/news/articles/SB10001424052702304026304579453253860786362.

Wacquant, Loïc. 2009. The Body, the Ghetto and the Penal State. Qualitative Sociology 32 (1): 10129.

Walker, Austin. 2015. The Rise of Twitch.tv: Talking Shop with Twitch.tv Execs and a Professional Twitch Streamer. Pastemagazine.com. Accessed May 11, 2015. http://www.pastemagazine.com/articles/2014/07/the-rise-of-twitchtv-talking-shop-with-twitchtvsv.html.

Whitney, Lance. 2014. Google Closes \$3.2 Billion Purchase of Nest. CNET. Accessed September 3 , 2015. http://www.cnet.com/news/google-closes-3-2-billion-purchase-of-nest/.

Wolf, Mark J. P. 2012. The Video Game Industry Crash of 1977. In Before the Crash: Early Video Game History. Detroit: Wayne State University Press.

Wright, Melissa W. 2001. Feminine Villains, Masculine Heroes, and the Reproduction of Ciudad Juarez. Social Text 19 (4): 93-113.

\section{About the Authors}

Daniel Greene

Daniel Greene is a PhD candidate in American Studies at the University of Maryland and a University Flagship Fellow. His ethnographic research focuses on the origins and effects of the hope that Internet access and Internet industries and will lift up people, cities, and countries. He is drawing on years of fieldwork among Washington, DC's tech start-ups, public libraries, and charter schools, in order to build a political economy of the so-called digital divide and show how wealth and poverty are produced and understood in cities trying to kickstart their tech sectors. Other current projects look at the economic geography of digital labour and the ethical arguments of drone warfare memes. He can be found online at dmgreene.net.

\section{Daniel Joseph}

Daniel Joseph is currently a Ph.D. student and researcher at Ryerson and York Universities in their Communication and Culture program. He is also a member of the Counterpublics Working Group at Robarts Centre for Canadian Studies at York University. He has written extensively about the politics at the heart of the knowledge economy, independent video game development, cultural policy and contemporary philosophy. His dissertation looks at how digital distribution and marketplace platforms like Valve Corporation's Steam change and reshape how play and work are discursively understood and materially practiced. 